\title{
WIRTUALNE ŻYCIE PO ŚMIERCI. DOŚWIADCZANIE ŚMIERCI NA FACEBOOKU
}

\section{Abstract \\ VIRTUAL LIFE AFTER DEATH. EXPERIENCE OF DEATH AT FACEBOOK}

Experiencing death is one of the elements of life that has found its place on the Net. Elements of social life published on the Internet are repeatedly interpreted and read by their users. The world of the Internet exists parallel to the real world. Death has its virtual representations. There are voices saying that the Internet, which is an electronic form of commemorating people, is "better than a material form of commemorating the deceased, because (...) it will survive as long as the Internet survives". Experiencing, commemorating and celebrating one's own and someone else's death on the Internet in the face of the "virtual presence of others" is no longer just reserved for Blog or virtual cemeteries but has moved to the Facebook platform. The accounts of the deceased on this platform are in the form of virtual tombstones, often run by people closely associated with the account owner. The subject of my analysis was content (moderator posts, guest posts posted in the comments) posted on the Facebook social network, assigned to an active account called "Anna Przybylska". I have reduced the analysis to the interpretation of images, signs and photographs to show how these contents (representations of death) influence the way Facebook experiences them. This analysis was used to find the answer to the question: How and to what extent Facebook allows Internet users to experience (through the interpretation of someone else's death and accompanying images) mourning. The text takes the form of research investigations combined with multi-faceted considerations about death in contemporary culture, in particular manifested by mass communication.

Key words: Facebook, the experience of death, mourning on-line, the experience of death on-line, narrative on the Internet, experience marketing 
Najsilniejsze wrażenie wywołuje śmierć pojedyncza, wyodrębniona, zabierająca jednego człowieka, którego rysy możemy określić, a nazwisko wymienić1.

\section{Badania jakościowe w Internecie. Badania własne}

Internet wykorzystywany jest obecnie niemal w każdym paradygmacie metodologicznym: w badaniach eksperymentalnych, sondażowych oraz jakościowych ${ }^{2}$. Badania jakościowe z wykorzystaniem metody biograficznej wydają się dostarczać rzetelnej odpowiedzi na pytanie: $w$ jaki sposób i na ile Facebook umożliwia internautom doświadczanie (poprzez interpretację cudzej śmierci i towarzyszących jej obrazów) żałoby? Przedmiotem badań uczyniłam fanpage Anny Przybylskiej, który jest wirtualnym pamiętnikiem zmarłej aktorki. Metoda biograficzna zajmuje się analizą dzienników oraz innych dokumentów biograficznych, do których należy zaliczyć: pamiętniki, listy, autobiografie. Dokument biograficzny to każde „sprawozdanie z doświadczenia jednostki, przedstawiające jej działalność jako człowieka i uczestnika w życiu społecznym". todą badań, lecz stanowi konglomerat różnych metod badawczych, łącznie z ich technikami obejmującymi analizę dokumentów (archiwaliów), obserwację, metodę sondażu diagnostycznego oraz metodę dialogową. $Z$ tego względu nazywana jest często metodą badań biograficznych, metodą analizy dokumentów osobistych lub dokumentów ludzkich. Badanie polega na opisie i analizie wycinka przebiegu życia ludzkiego lub wycinka rzeczywistości. Znaczenia nabiera tu całościowy bądź fragmentaryczny przebieg życia badanych związany z pełnioną funkcją społeczną lub kluczowe momenty życia skupione wokół ważnych wydarzeń historycznych ${ }^{4}$. Jedną z form dokumentu osobistego jest pamiętnik. Pamiętniki to „pisemne wypowiedzi, które relacjonując udział piszącego w pewnej sytuacji społecznej, zawierają także osobisty pogląd na te sytuacje, opis przebiegu zdarzeń, jakie miały w niej miejsce, i opis zachowania autora" ". Pamiętniki są dokumentami, które mogą być rejestrowane w różny sposób. Najczęściej przybierają one formę pisemną, mogą być nagraniami na taśmie magnetofonowej ${ }^{6}$ lub mieć postać wirtualną. W tym przypadku

${ }^{1}$ R. Kapuściński, Lapidaria, Agora, Warszawa 2008, s. 415-416.

2 J.M. Zając, K. Krejtz, Internet jako przedmiot i obszar badań psychologii społecznej, „Psychologia Społeczna" 2007, t. 2, nr 3-4 (5) 191-200, s. 192.

3 J. Szczepański, Metoda biograficzna, w: idem, Odmiany czasu biograficznego, PWN, Warszawa 1973, s. 619-620.

${ }^{4}$ S. Juszczyk, Badania jakościowe w naukach społecznych. Szkice metodologiczne, Wydawnictwo Uniwersytetu Śląskiego, Katowice 2013, s. 132.

${ }^{5}$ J. Szczepański, op. cit., s. 624.

${ }^{6}$ B. Szatur-Jaworska, Analiza pamiętników jako metoda badawcza w nauce o polityce społecznej, „Problemy Polityki Społecznej. Studia i dyskusje” 2001, nr 3, s. 3. 
będzie to analiza postów relacjonujących życie Anny Przybylskiej z czasu zmagania się $\mathrm{z}$ chorobą nowotworową, zawartych $\mathrm{w}$ wirtualnym pamiętniku.

Wirtualny pamiętnik pozwala na zachowanie swojego konta na Facebooku po śmierci. Osoby zmarłe mogą być nadal właścicielami konta, a ich bliscy mogą przekształcić je w konta „in memorial”, przedkładając skan aktu zgonu i nekrologu właściciela konta. Na koncie pozostają wówczas podstawowe informacje o jego dawnym użytkowniku, ale usuwane są wszelkie aktywności (funkcja potwierdzania nowych znajomości). Profil jest nadal dostępny, natomiast znajomi mogą zamieszczać tam informacje z kondolencjami. Wirtualne pamiętniki często prowadzone są przez osoby bliskie zmarłych osób, które umieszczają na nich posty związane ze znaczącymi wydarzeniami w ich życiu. Osoby te często piszą o swoich emocjach, publikują fotografie pamiątkowe i opisują towarzyszące im uczucia. Facebookowe konta osób zmarłych przekształcone w wirtualne pamiętniki stanowią pamiątkę dla ludzi, którzy byli im bliscy ${ }^{7}$. Istnieniu wirtualnego pamiętnika sprzyjają rozwiązania technologiczne. Aplikacja If I Die (Jeśli umrę) pozwala pozostawiać wiadomość, która zostanie opublikowana po śmierci użytkownika Facebooka. Może to być wideo, fotografia lub informacja tekstowa. Treść ta zostanie udostępniona wszystkim dotychczasowym znajomym zmarłego, którzy będą mogli ją komentować. Aplikacja LivesOn, promowana pod hasłem: „When your heart stops beating, you'll keep tweeting" (Gdy Twoje serce przestanie bić, będziesz nadal tweetował), daje możliwość kontynuowania życia na Facebooku, Twitterze oraz LinkedIn. Specjalny algorytm pozwala śledzić wpisy wybranych użytkowników na portalach społecznościowych. Po ich śmierci na wybranym portalu społecznościowym wykorzystuje on zebrane informacje do publikowania wiadomości oraz linkowania stron w taki sam sposób, z podobną konsekwencją i upodobaniem co jego właściciel ${ }^{8}$. Zarówno w przypadku kont aktualizowanych przez osoby bliskie ludziom zmarłym, jak i tych sterowanych komputerowo mamy do czynienia $\mathrm{z}$ wirtualnym, pośmiertnym pamiętnikiem, który pozostawia osobę zmarłą nadal aktywną na Facebooku. Konto takie internauci nazywają pamiętnikiem, ponieważ zamieszczane na nim treści relacjonujące przebieg życia i najważniejsze wydarzenia dotyczące zmarłej osoby są nadal dostępne i można je stale od nowa odczytywać, wracając do nich pamięcią. Traktowaniu przez internautów zmarłych ludzi jako wirtualnych pamiętników sprzyja oś czasu, na której zaznaczane są najistotniejsze momenty z życia jego właściciela.

Wirtualny pamiętnik oprócz możliwości publikowania w nim postów związanych z kluczowymi wydarzeniami z życia jego właściciela jest często miejscem dzielenia się przez internautów własnymi doświadczeniami związanymi z przeżywaniem

7 Życie po śmierci na Facebooku, 26.09.2017, http://kobieta.onet.pl/zdrowie/psychologia/zycie-po-smierci-na-facebooku/ty7ck [dostęp: 17.02.2017].

${ }_{8}$ Wirtualne życie po życiu - posty na Facebooku i Twitterze po śmierci, 29.20.2013, http://tech. wp.pl/wirtualne-zycie-po-zyciu-posty-na-facebooku-i-twitterze-po-smierci-6034800493142657a [dostęp: 17.02.2017]. 
żałoby. To również przestrzeń dzielenia się reflacjami na temat przemijania, a także kierowania komunikatów w stronę zmarłych osób opisujących doświadczanie samotności. Wirtualne pamiętniki często nazywane są „wirtualnymi cmentarzami” ze względu na możliwość złożenia kondolencji osobom spokrewnionym ze zmarłym. Internauci komentujący posty na profilu Anny Przybylskiej są przekonani, że zamieszcza je matka zmarłej aktorki, dlatego często wyrazy współczucia i żalu kierują w jej stronę. Ponadto komentarze zamieszczane pod postami charakteryzują się użyciem wirtualnego języka w postaci znaków wyrażających określone emocje. Można tu również zapalić elektroniczny znicz.

Głównym przedmiotem analizy uczyniłam narrację, która prezentowana jest na Facebooku i przypisana została zmarłej „Annie Przybylskiej”, ponieważ to ona - rozumiana przeze mnie jako system znaków, obrazów i treści - nadaje temu rodzajowi pamiętnika szczególne znaczenie. Narracja to zatem „uniwersum znaczeń, które wymagają od człowieka stałej interpretacji, polegającej na odczytywaniu znaczeń, sytuacji czyjegoś oraz własnego losu”" „Rozumiemy to, co się z nami i innymi dzieje, w postaci odczytywanych przez nas opowieści, docierających do nas narracji”" Analizowany przeze mnie przypadek wpisuje się w praktyki doświadczania śmierci i żałoby przez innych użytkowników Facebooka i jest modelowym przykładem tego, w jaki sposób dzięki wykorzystaniu technologii informacyjnych zaciera się granica między życiem a śmiercią, a także tego, że mamy do czynienia z nowym sposobem przeżywania żałoby w sensie indywidualnym i zbiorowym. Metaforyczność przekazów medialnych i interpretacja znaczeń w postaci tekstu i obrazu zabiera dziś użytkownika sieci w podróż, której zasadniczym celem jest doświadczanie poprzez doświadczenie własne i innych użytkowników sieci.

\section{Śmierć w Internecie. Reprezentacje śmierci na Facebooku}

Facebook jest miejscem rozgrywania się i reprezentacji śmierci. 7 lipca 2016 roku świat obiegł film zamieszczony przez Lavish Reynolds, która nagrała śmierć swojego chłopaka, postrzelonego podczas rutynowej kontroli drogowej w Minnesocie. Reynolds transmitowała całe wydarzenie na żywo, błagając użytkowników Facebooka, aby przyjechali na miejsce i pomogli ratować jej chłopaka, kiedy ten stracił przytomność ${ }^{11}$.

${ }^{9}$ M. Nowak-Dziemianowicz, Czy świat człowieka ma postać narracji? O możliwościach badania, rozumienia, zmiany, w: E. Kurantowicz, M. Nowak-Dziemianowicz (red.), Narracja - krytyka zmiana - praktyki badawcze, DSWE TWP we Wrocławiu, Wrocław 2007, s. 14.

${ }^{10}$ Ibidem.

${ }^{11}$ Kobieta relacjonowała na Facebooku... zastrzelenie swojego chłopaka! „Boże, nie pozwól mu umrzeć, on jest niewinny!", http://www.pudelek.pl/artykul/94931/kobieta_relacjonowala_na_facebooku_ zastrzelenie_swojego_chlopaka_boze_nie_pozwol_mu_umrzec_on_jest_niewinny/\# [dostęp: 13.02.2017]. 
Śmierć na Facebooku transmitowana na żywo ma charakter przypadkowy lub zamierzony. 26-letnia Keiana Herndon zmarła na skutek uduszenia, transmitując to zdarzenie na żywo swoim znajomym. Przez kilka sekund obserwowali oni próby złapania przez nią oddechu zakończone upadkiem na ziemię i zgonem ${ }^{12}$. Podobnie swoją śmierć na Facebooku transmitował skoczek z Włoch, 28-letni Armin Schmieder w pobliżu szwajcarskiego miasta Kandersteg. Na nagraniu można było zobaczyć jak z niewiadomych powodów skoczek nagle spada na ziemię i umiera ${ }^{13}$.

Przypadek umyślnego użycia Facebooka z zamiarem nagrania własnego samobójstwa zdarzył się 13 stycznia 2017 roku i został zarejestrowany przez nastolatkę Katelyn Nicole Davis. Dziewczyna na oczach internautów odebrała sobie życie, wieszając się na drzewie ${ }^{14}$.

Znane są również przypadki pozostawiania pożegnań na Facebooku przez osoby, które czekają na śmierć. Na kilka dni przed końcem swojego życia 30-letni Eric L. Ramsey pożegnał się ze znajomymi za pośrednictwem portalu społecznościowego, publikując na swojej tablicy informację: „Cóż, ludziska, za chwilę mnie

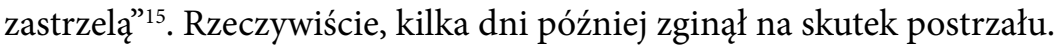

Facebook to również miejsce, w którym bliscy żegnają zmarłe osoby. Przykładem może być zamieszczenie przez żonę zmarłego Tomasza Kality posta $\mathrm{z}$ fragmentem utworu Blues pogrzebowy $\mathrm{z}$ adnotacją: „Będę zawsze tęsknić” ${ }^{16}$. Podobnie, korzystając z Facebooka, 6 października pożegnała swoją przyjaciółkę, Beatę Maciejewską-Welfle, Anna Lewandowska, dedykując zmarłej za pomocą swojego profilu teledysk w wykonaniu Justyny Steczkowskiej Wracam do domu ${ }^{17}$.

Warto wspomnieć, że ze względu na swój zasięg Facebook pełni również funkcję informatora o zdarzeniach śmiertelnych. Tylko w 2012 roku tysiące osób na Facebooku obwieściło swoje uczestnictwo w wypadku śmiertelnym ${ }^{18}$. Konta osób

${ }_{12}$ Kobieta umierała podczas transmisji live na Facebooku. Nikt $z$ oglądających jej nie pomógt, 3.01.2017, http://noizz.pl/spoleczenstwo/facebook-keiana-herndon-zmarla-podczas-transmisji-live/ny9nqfq [dostęp: 13.02.2017].

13 Skoczek transmitował swoją śmierć na żywo na Facebooku, 21.08.2016, http://pikio.pl/skoczek-transmitowal-swoja-smierc-na-zywo-na-facebooku-video/\# [dostęp: 13.02.2017].

${ }^{14}$ Nastolatka popetniła samobójstwo, transmitując je na żywo na Facebooku, 13.01.2017, http:// www.newsweek.pl/swiat/spoleczenstwo/nastolatka-popelnila-samobojstwo-transmitujac-je-na-zywo-na-facebooku,artykuly,403438,1.html [dostęp: 12.02.2017].

${ }_{15}$ Pożegnat się ze znajomymi na Facebooku i zaraz potem został zastrzelony, 21.01.2017, http://tech.wp.pl/pozegnal-sie-ze-znajomymi-na-facebooku-i-zaraz-potem-zostal-zastrzelony-6034886643451009a [dostęp: 13.02.2017].

16 Żona Tomasza Kality pożegnała go na Facebooku. „Będę zawsze tęsknić, 17.01.2017, http:// noizz.pl/spoleczenstwo/zona-tomasza-kality-pozegnala-go-na-facebooku-bede-zawsze-tesknic/ pkjc84n [dostęp: 13.02.2017].

17 Anna Lewandowska pożegnała zmarła przyjaciółkę. Beata Maciejewska-Welfle nie żyje, 2.12.2016, http://www.pomponik.pl/plotki/news-anna-lewandowska-pozegnala-zmarla-przyjaciolke-beata-macieje,nId,2316389 [dostęp: 13.02.2017].

${ }^{18}$ E. Gietka, Wirtualne życie umarlych. E-umarli, http://www.polityka.pl/tygodnikpolityka/ ludzieistyle/1559775,1,wirtualne-zycie-umarlych.read [dostęp: 10.04.2015]. 
zmarłych często automatycznie przekształcają się w wirtualne pamiętniki z uwagi na aktywność w nich osób trzecich.

Marcin, 27-letni student AWF-u, został pobity i śmiertelnie ugodzony nożem. Piętnaście minut po tym, jak policjanci przekazali jego dziewczynie, Iwonie, informację o śmierci, ta zalogowała się na Facebooku w swoim iPhonie i oznaczyła Marcina w poście „Mój chłopak nie żyje”, który skomentowało ponad 350 osób. Znajomi nie mogli uwierzyć w to, co się stało, pytali o datę pogrzebu, oferowali swoje wsparcie. Po kilku dniach charakter wpisów nieco się zmienił. Użytkownicy zaczęli wspominać Marcina, wymieniać się zdjęciami. Jego brat umieścił fotografię $\mathrm{z}$ dzieciństwa, a narzeczona film $\mathrm{z}$ wakacji, które spędzili razem ${ }^{19}$.

Zdarza się, że decyzja o pozostawieniu konta zmarłej osoby nie podlega dyskusji.

Nie wysyłałam do Marcina prywatnych wiadomości, bo wiedziałam, że pozostaną one bez odpowiedzi. Komunikowanie się z jego przyjaciółmi pomagało mi w przepracowaniu traumy po stracie kogoś, z kim spędziłam ostatnie pięć lat swojego życia - wspomina Iwona. Ani ona, ani rodzice Marcina nie zabiegali o to, by usunąć jego facebookowe konto. Dzięki temu on wciąż jest w pewnym sensie obok nas $(. . .)^{20}$.

Wychodząc naprzeciw oczekiwaniom internautów, administratorzy Facebooka w Stanach Zjednoczonych umożliwili użytkownikom sieci wskazanie osoby, która po ich śmierci będzie prawnym administratorem konta i w dalszym ciągu będzie prowadziła stronę. W ten sposób konta zmarłych użytkowników Facebooka mają stać się „pomnikami życia, przyjaźni i doświadczenia”21.

\section{Śmierć na Facebooku - wirtualny pamiętnik Anny Przybylskiej}

Analiza konta zmarłej Anny Przybylskiej pozwala zaobserwować, że elementy i symbole nawiązujące do poczucia straty i żalu (fotografia, wpisy zmarłej i jej rodziny pod fotografiami pamiątkowymi, komentarze pod zdjęciami, emotikony) tworzą nową jakość łączenia się ludzi w żałobie. Fotografie i wspomnienia zamieszczone na analizowanej stronie budują wizerunek zmarłej i określają jej tożsamość. Uwydatniają jej określone cechy i nadają im znaczenie. Elementy te sprawiają, że osoby będące fanami łączą się w bólu z rodziną zmarłej, prowadząc między sobą wirtualny dialog, podsycany pytaniami o egzystencję człowieka. Internauci są przekonani, że strona administrowana jest przez matkę aktorki lub jej menedżerkę, które w ten sposób postanowiły uczcić pamięć zmarłej. O ważności i misyjności tego

${ }^{19}$ M. Mikołajska, op. cit.

${ }^{20}$ Ibidem.

${ }^{21}$ Co dzieje się z kontem na Facebooku po śmierci? Teraz można o tym zdecydować, http://www. tvp.info/18835527/co-dzieje-sie-z-kontem-na-facebooku-po-smierci-teraz-mozna-o-tym-zdecydowac [dostęp: 10.04.2015]. 
przedsięwzięcia świadczy to, że nazywane jest przez nich samych „kontem-wspomnieniem". Tymczasem menedżer i przyjaciółka zmarłej Małgorzata Rudawska podkreśla, że ani rodzina, ani ona nie są administratorem profilu Anny Przybylskiej na Facebooku, co potwierdzają doniesienia prasowe i moja prywatna korespondencja z menedżerem aktorki. Niemniej jednak konto to od czasu śmierci Przybylskiej pozostaje aktywne i liczy obecnie 230474 fanów, którzy udostępniają, śledzą i komentują posty zamieszczone na Facebooku. Użytkownicy Facebooka odwiedzający profil zmarłej kierują swoje komunikaty bezpośrednio do osoby, która nim zarządza, licząc na odpowiedź („Pani Krysiu”, „Do mamy Ani”, „Szanowna Pani”). Widać wyraźnie, że są przekonani, iż profil ten prowadzi matka zmarłej. Oto przykłady takich wypowiedzi:

Bożena Andrejuk: Szanowna Pani, proszę przyjąć wyrazy współczucia z powodu odejścia córki. Może być Pani z Niej dumna, była wspaniałą, uroczą kobietą, mamą, żoną, aktorką, kochała Ją ogromna rzesza ludzi. Pozostawiła swoje najukochańsze dzieci, a Pani wnuczęta, które będą dla Pani pociechą i podporą. Życzę Pani dużo zdrowia, miłości od wnucząt i przetrwania tych trudnych chwil.

Źródło: https://www.facebook.com/aniablond?fref=ts, 11.12.2014.

Agnes Blacknecka: Pani Krysiu, byłam dziś u Pana Boga na kawie - znów się zaczynamy kumplować, bo Go nieco zaniedbałam i Ania mi przypomniała o pielęgnowaniu tej relacji.

Źródło: https://www.facebook.com/aniablond?fref=ts, 11.12.2014.

Madzia Tomas Adamska Olszewski: Do mamy Ani. Za to, że dałaś światu tak cenną osobę, dziękujemy! [*]

Źródło: https://www.facebook.com/aniablond?fref=ts, 11.12.2014.

Użytkownicy śledzą również doniesienia prasowe na temat tego, kto jest administratorem strony, i prowadzą między sobą dialog o sensowności istnienia pamiętnika. Wierzą w jego terapeutyczną moc jednoczenia się w bólu i współprzeżywania żałoby. Prowadzenie pamiętnika jest dla nich formą przeżywania żałoby.

Lidia Jolanta: Ani profil prowadzi jej menagerka, która zapewne też bardzo tęskni i cierpi... a fotografie pozostaną na zawsze... ja chcę właśnie ją taką zapamiętać...

Margaret Ta: Rodzina ma prawo przeżywać żałobę jak uważa za stosowne i może to dla nich jest forma wspominania zmarłej...

Źródło: https://www.facebook.com/aniablond?fref=ts, 11.12.2014.

Ewa Jakubiak-Szydłowska: Po śmierci użytkownika można profil usunąć, ale ktoś z rodziny czy menadżer może taki profil nadal prowadzić. Lepiej poinformujcie bliskich, co mają zrobić, jak Was zabraknie, zamiast tutaj wylewać swoje gorzkie żale. Widocznie taką decyzję podjęła rodzina Ani. 4 listopada o 07:37.

Źródło: https://www.facebook.com/aniablond?fref=ts, 11.12.2014. 
Asia Izdebska: Gdyby rodzina tego sobie nie życzyła, z pewnością ten profil zostałby zlikwidowany, a Pani Rudawska nie udzieliłaby wywiadu magazynowi „Viva”. Myślę, że dla niektórych osób ma to duże znaczenie, bo Ania pozostanie dla nich kimś ważnym.

Źródło: https://www.facebook.com/aniablond?fref=ts, 11.12.2014.

Wirtualny pamiętnik, „konto-wspomnienie” czy „wirtualny cmentarz” ma określoną budowę. W tym przypadku na fanpage'u pojawiają się cyklicznie wypowiedzi bliskich aktorce osób opisujących sytuacje z czasu przebiegu choroby Anny, jej walkę $z$ chorobą, a także wspomnienia związane $z$ jej codziennością. Zamieszczane są również informacje prasowe o stanie zdrowia aktorki, zdjęcia oraz cytaty pozyskane z wywiadów prasowych, których bohaterami były osoby bliskie Przybylskiej lub ona sama. Profesjonalne fotografie, ukazujące ją często w sytuacjach rodzinnych, uwydatniają tragizm jej śmierci, uświadamiają odbiorcy, jak niesprawiedliwa i nagła może być, potęgują poczucie straty i żalu. Kobiety śledzące stronę utożsamiają się z osobą prezentowaną na zdjęciu, co znajduje swój wyraz w zamieszczanych komentarzach. Nic dziwnego, ponieważ w materiałach prezentowanych w wirtualnym pamiętniku Anna Przybylska przybiera postać atrakcyjnej kobiety świadomej własnej seksualności, jednak nie wulgarnej. Fotografie, na których eksponuje swe ciało, także w towarzystwie dzieci i partnera, sprawiają wrażenie, że ich bohaterka rządzi swoim życiem i biografią, idealnie wpasowuje się w otaczającą ją rzeczywistość. Macierzyństwo będące wynikiem jej świadomego wyboru, pozostawiając jej ciało $\mathrm{w}$ idealnej formie, jawi się tu jako jeden $\mathrm{z}$ wielu zrealizowanych celów biograficznych aktorki. Tym samym Anna Przybylska stała się wzorem kobiety-matki, z którą należy się identyfikować. Informacje zamieszczone pod zdjęciami - wybrane wycinki wypowiedzi zmarłej aktorki - „uczłowieczają” postać na zdjęciu: internauta ogląda piękną, spełnioną w każdej możliwej dziedzinie życia kobietę-matkę, której egzystencja to nieustanna walka ze swoimi słabościami i rutyną dnia codziennego. Tymczasem w tej walce to zawsze ona wygrywa. Zabieg ten uwydatnia tragizm śmierci, która staje się bardziej oswojona, bliska własnemu doświadczeniu. Postać Anny Przybylskiej oglądana na Facebooku przypomina obraz postfeministki z typowymi dla niej cechami: to kobieta wolna, która może być, kim chce (doskonale odnajduje się w prezentowanych na Facebooku stylizacjach), uosabia kult pięknego ciała, jest odważna; to waleczna bohaterka swojego życia ${ }^{22}$. Co więcej, Przybylska nie jest „telewizyjną kometą”. Styl jej twórczości i tożsamości stanowi źródło trwałego sukcesu ${ }^{23}$. Warto zauważyć, że aktorka od czasu rozpoczęcia swojej kariery, kojarzonej z rolą w serialu Złotopolscy, przeszła przemianę: ewoluowała od skromnej serialowej policjantki do pewnej siebie i potrafiącej odwołać się do swoich doświadczeń dobrej matki, twarzy kampanii reklamowej marki CCC, modelki „Playboya” i twarzy firmy

${ }^{22}$ A. Gromkowska-Melosik, Od skromnej dziewczyny z sąsiedztwa do bohaterki postfeministycznego świata, „Studia Edukacyjne” 2015, nr 36, s. 137.

${ }^{23}$ Ibidem, s. 138. 
kosmetycznej ${ }^{24}$. Wszystkie te role pozostały w pamięci Polaków głównie dzięki temu, że w mediach istniał i nadal istnieje jej wizerunek jako kobiety ciepłej, troskliwej, pozytywnie nastawionej do życia i świata. Fanpage podtrzymuje ten wizerunek, sięgając do publikowanych już w mediach zdjęć aktorki, a jego istnienie nie jest odbierane przez zrzeszających się wokół niego fanów jako chwyt marketingowy. Wiara w autentyczny, niecelowy, zgodny z wyobrażeniem społecznym przekaz uruchamia prawdziwe uczucia odbiorców. Ponadto ludzie odwiedzający fanpage Anny Przybylskiej prezentują drugie i trzecie stadium syndromu absorpcji-uzależnienia opisywanego przez McCutcheona, Langego i Hourona, zgodnie z którym fani pragną kształtować swoją tożsamość poprzez psychologiczną absorpcję tożsamości medialnego idola, co daje im poczucie spełnienia. W modelu tym można wyróżnić trzy stadia uwielbienia dla idola: rozrywkowo-społeczne, odznaczające się niskim poziomem uwielbienia, który wiąże się z doraźną przyjemnością; intensywno-osobiste - średni poziom uwielbienia związany z doznawaniem silnych uczuć w związku z postacią idola, a także obsesyjnym myśleniem o nim; ekstremalne - oznaczające bezgraniczne oddanie się idolowi ${ }^{25}$. Tym samym Anna Przybylska dla internautów stała się ikoną. Jest rozpoznawalna przez większość społeczeństwa, a jej tragiczna śmierć potwierdziła ten status ${ }^{26}$. Warto dodać, że analiza fanpagéa Anny Przybylskiej pozwala dostrzec, iż prezentuje on szeroką gamę wzorów tożsamości, co sprzyja zwiększaniu liczby fanów na Facebooku. Zamieszczane tam posty dają możliwość definiowania poczucia własnej wartości łączących się w żałobie z rodziną aktorki matek, partnerek, córek, synów, wreszcie po prostu kobiet i mężczyzn. Posty nadają sens życiu tym, którzy kogoś stracili, stracą lub sami odejdą ${ }^{27}$. Stale rosnąca liczba fanów na profilu Przybylskiej, a także sposób komunikacji preferowany przez jego użytkowników pozwala zauważyć, że profil ten istnieje i rozwija się dzięki temu, że jego administratorom udało się stworzyć „interakcyjne środowisko doświadczeń współtworzenia”, które zapewnia internautom powtarzalność interakcji, będąc tym samym miejscem współtworzenia wartości ${ }^{28}$. Przykładem mogą być poniższe wpisy pojawiające się tuż pod komunikatami administratora strony. Wskazują one również na sposób interpretacji danego komunikatu i pozwalają określić emocje, które wywołuje on u odbiorców. Ich znaczenie można odczytać nie tylko za pomocą tekstu, ale także dzięki użyciu emotikonów czy wirtualnych oznaczeń. Przykładem może być elektroniczny znicz „[“]”.

${ }^{24}$ R. Daszczyński, Najdroższa twarz Pomorza. Role w filmach, promocja kosmetyków, sesje w Playboyu, a do tego wizerunek dobrej matki i żony. Jakim cudem Anna Przybylska to wszystko ła$c z y$ ?, 29.06.2017, http://trojmiasto.wyborcza.pl/trojmiasto/1,35636,14192156,Anna_Przybylska_na_ zakrecie_Portret_znanej_aktorki.html [dostęp: 1.03.2017].

${ }_{25}$ A. Gromkowska-Melosik, op. cit., s. 138.

${ }^{26}$ A. Gromkowska-Melosik, Ikony i idole popkultury. Taylor Swift $i$ Barbie jako wzory ciała i tożsamości młodzieży, w: J. Pyżalski (red.), Wychowawcze i społeczno-kulturowe kompetencje współczesnych nauczycieli, theQ studio, Łódź 2015, s. 45.

27 Ibidem, s. 46.

${ }^{28}$ G. Baran, Marketing wspóttworzenia wartości z klientem, Instytut Spraw Publicznych Uniwersytetu Jagiellońskiego, Kraków 2013, s. 144. 


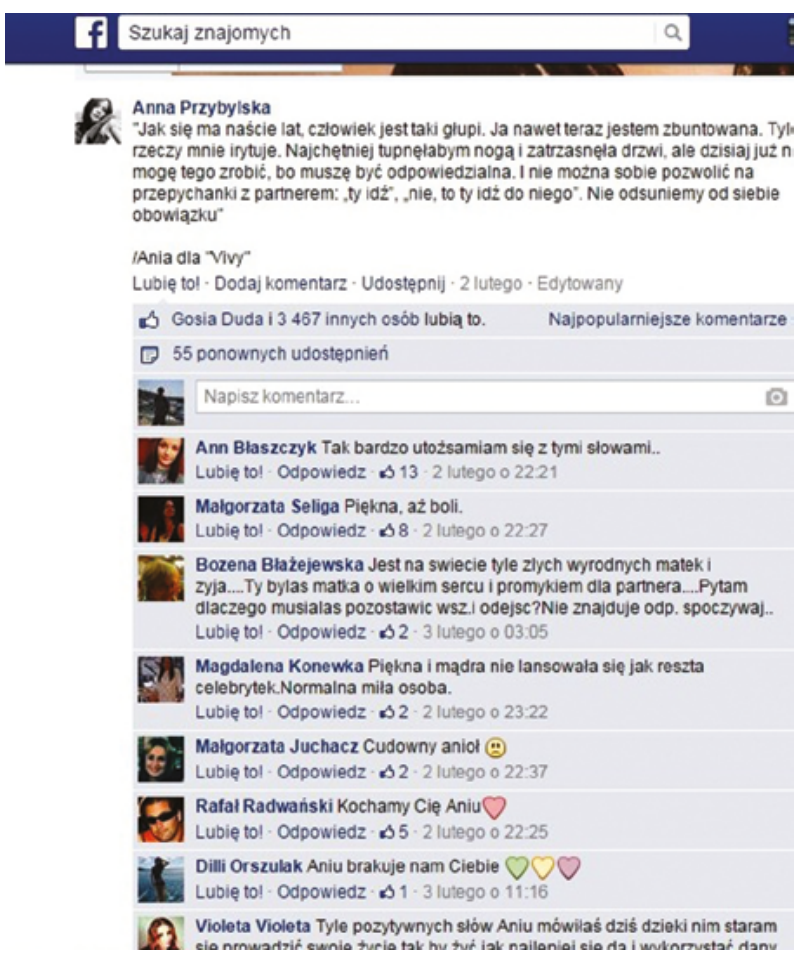

Zdjęcie 1. Screen z fanpage’a Anny Przybylskiej. Refleksja nad dorosłością i odpowiedzialnością w kontekście przemijania.

Źródło: https://www.facebook.com/aniablond/photos/a.661972200494099.1073741828.6328530134060 18/922964864394830/?type=1 [dostęp: 11.02.2015].

Agata Kolorz: W piątek po szkole mama była, w poniedziałek przed szkołą już nie miał kto śniadania zrobić. Strasznie mi żal dzieciaków.

https://www.facebook.com/aniablond?fref=ts, 11.12.2014.

Andżelika Worach: żadne pieniądze nie kupią miłości i zdrowia... Ania była kochającą i oddaną matką i żoną.

https://www.facebook.com/aniablond?fref=ts, 11.12.2014.

We wskazanych wyżej przykładach widać wyraźnie istotę siły przekazów medialnych, skoncentrowanych nie tyle na przekazaniu konkretnej informacji, ile na wyrażeniu pewnego rodzaju doświadczeń emocjonalnych, które niesie zawarta $\mathrm{w}$ nich informacja ${ }^{29}$. Wizerunek medialny Anny Przybylskiej funkcjonujący

${ }^{29} \mathrm{H}$. Witek, Śmiertelność - nieśmiertelność. Medialne konstrukcje i dekonstrukcje, w: A. Gralczyk, M. Laskowska, P. Drzewiecki (red.), Media wobec śmierci, t. 2: Tragizm, rozrywka, edukacja - różne obrazy śmierci w mediach jako przekroczenia tabu i śmierci, Dom Wydawniczy Elipsa, Warszawa 2012, s. 127. 
w mediach i sympatia widzów sprawiają, że uczucia i emocje wyzwalane przez obrazy w Internecie, o których piszą użytkownicy sieci, są prawdziwe. Magdalena Konewka komentująca post napisała: „Piękna i mądra, nie lansowała się jak reszta celebrytek. Normalna i miła osoba”. Mimo iż wobec prezentowanych treści można skierować zarzut nieprawdziwości i komercji, wydaje się, że o ile istnienie analizowanego konta swoje źródło może mieć w interesie ekonomicznym, o tyle służy ono dobru społecznemu, ponieważ zamieszczane na nim komentarze internautów wskazują na prawdziwe przeżywanie żałoby.

Piotr Siuda podaje, że $w$ istocie zarzut sztuczności i nieprawdziwości prezentowanych $\mathrm{w}$ Internecie informacji związanych $\mathrm{z}$ sakralnymi przeżyciami $\mathrm{w}$ żaden sposób nie podważa zasadności istnienia tego rodzaju portali i ich wpływu na kształtowanie się i przeżywanie duchowości przez ich użytkowników. Ludzie z cyberprzestrzeni tworzą sacrum, gdyż uważają, że przestrzeń ta jest odpowiednia do doznawania religijnych doświadczeń. Przeżyciom wirtualnym nadaje się dziś znaczenia, które mają źródło w ludzkich wyobrażeniach. Rytuały internetowe są pełnoprawne i prawdziwe, bo mieszczą się w umysłach ludzkich: „Gdyby internauci nie wierzyli w możliwość przywołania Boga, gdyby nie wierzyli w to, że $\mathrm{w}$ cyberprzestrzeni rytuały mają takie samo znaczenie jak w realu, nie byłoby sensu ich odprawiać"30. Podobnie na temat nadawania prawdziwych znaczeń obrazom śmierci w mediach pisze Ewa Jeleń-Kubalewska, zauważając, że zabiegi polegające na wizualnych reprezentacjach śmierci i jej kontekstu pozwalają na uwolnienie represjonowanych emocji, wyrażenie smutku i żałoby ${ }^{31}$. W przypadku wirtualnego pamiętnika Anny Przybylskiej tekst i obraz stanowią integralną całość, a ich konstrukcja wpływa na sposób odczytania znaczenia zamieszczonego poniżej komunikatu, który spełnia swoje zadanie: intensyfikuje potrzebę dzielenia się refleksją nad znaczeniem życia i śmierci w egzystencji ludzkiej. Widać wyraźnie, że prezentowane na fanpage'u obrazy sprzyjają tworzeniu się i podtrzymywaniu relacji między osobą z Internetu a jego uczestnikiem. Relacja ta jest oparta na wspólnych wyobrażeniach związanych $\mathrm{z}$ doświadczaniem określonych sytuacji czy też wypełnianiem w życiu określonych ról - w tym przypadku żony i matki. Doświadczenie z punktu widzenia nauk o zarządzaniu stanowi wewnętrzną i subiektywną odpowiedź na bezpośrednią lub pośrednią interakcję między podmiotami w czasie trwania ich relacji i prowadzi do zaangażowania emocjonalnego, racjonalnego, zmysłowego, duchowego i fizycznego. Ten rodzaj rzeczywistego doświadczania widoczny jest u osób aktywnych na profilu. Co więcej, doświadczenia te nie powstają spontanicznie i przypadkowo, lecz są wywoływane poprzez oddziaływanie na odbiorcę. W przypadku przedsiębiorstw oddziaływania przybierają charakter

${ }^{30} \mathrm{P}$. Siuda, Religia a Internet. O przenoszeniu religijnych granic do cyberprzestrzeni, Wydawnictwa Akademickie i Profesjonalne, Warszawa 2010, s. 88.

${ }^{31}$ E. Jeleń-Kubalewska, Cierpienie i śmierć jako współczesny performans medialny. Perspektywa performatywna, Praca doktorska sfinansowana przez Narodowe Centrum Nauki jako projekt badawczy w ramach konkursu „Preludium”, Poznań 2014, s. 9. 
inscenizowanych wydarzeń, podczas który dane produkty są nośnikami doznań ${ }^{32}$. Tutaj mamy do czynienia $\mathrm{z}$ fotografią i tekstem, z prezentowaniem fotografii występujących zawsze w jakimś kontekście; fotografie i tekst to nośnik autentycznych doznań odbiorców. To swoisty marketing doświadczeń. Jeśli przeżycie jest autentyczne, w procesie interakcji staje się unikatowym, osobistym, niezapomnianym i trwałym doznaniem ${ }^{33}$.

Na zdjęciach w ramach fanpage’a widać silną, piękną, szczupłą, waleczną, dobrze ubraną, perfekcyjną, atrakcyjną kobietę-matkę w atrakcyjnej scenerii, dającą poczucie bezpieczeństwa swoim dzieciom. Większość postów na Facebooku ma tę samą konstrukcję. Po ich lekturze czytelnikowi jawi się obraz kobiety pogodzonej z losem, oddającej swoje życie w ręce Stwórcy, świadomej nadejścia sytuacji, w której zmuszona będzie do opuszczenia swych bliskich. Kobiety jednak nadal silnej, walecznej, zmagającej się z życiem codziennym. Płacz będący tu oznaką słabości jest po stronie narratorki. Obrazy przypominają o tym, jak przewrotny i zarazem okrutny jest los. Nawiązują również do kruchości świata codziennego, a także związanego z tym cierpienia i elementu zrządzenia losu ${ }^{34}$ : „Jeszcze w piątek Ania pomogła Oliwce w lekcjach i zawiozła dzieci do szkoły (...). Ona wszystkim w domu rządziła (...). W sobotę była już bardzo słaba, siedziała w fotelu (...)"35. O tym, jak wiele kobiet identyfikuje się z Anną Przybylską, jak wiele osób doświadczyło, doświadcza lub spodziewa się doświadczyć cierpienia oraz jak wielką siłę wyobrażeniową niesie powyższy przekaz, świadczy ilość komentarzy pod tym przekazem. Ich liczba przekracza 460 narracji kobiet. Przybylska jawi się tu jako „Betroffene” - osoba dotknięta cierpieniem, osoba dotknięta nagle i niesprawiedliwie problemem, z którym musi żyć, a który zmienia dotychczasowy ład i porządek rzeczy; osoba dotknięta trajektorią cierpienia ${ }^{36}$. Prawidłowość ta widoczna jest w poniższych narracjach:

Justyna Marzec: tak, to prawda, była piękną, młodą aktorką, ale jeżeli przychodzi śmierć, nie ma wyższych, są tylko równi, czy idealny, czy bogaty, na każdego przyjdzie czas, niestety, choć dla Ani ten czas była za krótki zdecydowanie. 23 października 2014 o 14:39.

Źródło: https://www.facebook.com/aniablond?fref=ts.

Barbara Kucharczyk: To nie sama śmierć i odejście Ani jest w tym wszystkim najstraszniejsze, ale to, że przez ten okres żyła ze świadomością tej śmierci, z lękiem, bólem, żalem i z całą resztą tych uczuć, które odbierają oddech... to prawda, że takie tragedie skłaniają do refleksji... komu jest ciężej? Rodzinie, która została tutaj, czy Ani, która musiała pożegnać się i rozstać ze wszystkimi, których kochała? I to u mnie wywołuje lawinę łez...

${ }^{32}$ K. Dziewanowska, Nowe oblicze marketingu - koncepcja marketingu doświadczeń, „Marketing i Rynek" 2013, nr 1/20, s. 18.

${ }^{33}$ Ibidem, s. 19.

${ }^{34}$ F. Schütze, Trajektorie cierpienia jako przedmiot badań socjologii interpretatywnej, „Studia Socjologiczne" 1997, nr 1 (144), s. 13.

${ }_{35}$ Zob. https://www.facebook.com/aniablond/timeline [dostęp: 4.12.2014].

${ }^{36}$ F. Schütze, op. cit., s. 15-16. 
Ania jest odzwierciedleniem każdej takiej tragedii, która spotyka różnych ludzi... Jedno jest pewne, że niesprawiedliwe jest to, że przytrafia się to tym, którzy kochają, szanują i cieszą się z tego! Ania umierała ze świadomością, że dzieci zostają ze wspaniałym ojcem, i myślę, że to jej dodawało mimo wszystko otuchy i uspokajało...

Źródło: https://www.facebook.com/aniablond/timeline, 4.12.2014.

\section{Sposób doświadczania śmierci przez internautów - przykład konta Anny Przybylskiej}

Identyfikacja z idolem żyjącym w cieniu śmierci sprzyja stawianiu pytań egzystencjonalnych. Posty ukazujące się na omawianym profilu zostały tak skonstruowane, aby ich odbiorca miał szansę podglądnięcia życia bohatera w czasie jego zmagania się z chorobą. Świadomość człowieka może przedstawić świat tylko wtedy, gdy powstanie w niej obraz - wyobrażenie pewnego zjawiska lub podmiotu, które jest nie do wyobrażenia ${ }^{37}$. Internet dzięki swoim możliwościom wydaje się do tego idealnym miejscem. Mateusz Zimnoch zauważa, że „współcześnie temat śmierci jest świadomie przenoszony ze strefy życia społecznego do środków masowego przekazu, będących główną przyczyną jej obecności, a z drugiej strony jednym $z$ podstawowych narzędzi jej oswajania" ${ }^{38}$. Jak to zatem będzie, gdy mnie spotka podobny los? Czy moje refleksje będą podobne do tych, które zamieszczone są na koncie Anny Przybylskiej? A może ich lektura pozwoli mi odkryć tajemnicę śmierci, która przecież jest nieuchronna? - pytają internauci. Klikam więc dalej.

Śmierć własna jest pojmowana pod postacią wyobrażeń. Człowiek, będący istotą żyjącą w świecie uczuć, nadziei, lęków i radości, złudzeń, marzeń i iluzji, pod wpływem obcowania z czyjąś śmiercią tworzy sobie jej wyobrażenie. Swoje imaginacje o niej buduje za pomocą obrazów i ich interpretacji, dlatego każdy może nadać jej dowolne znaczenie. Istotę ludzką przerażają jej niepokoje, wyobrażenia oraz iluzje o rzeczach i zdarzeniach. Pod wpływem stałego obcowania z obrazem śmierci w nowych mediach człowiek może na nowo konstruować obraz siebie w sytuacji choroby, zagrożenia życia. W związku z tym, że nikt nie ma bezpośredniego dostępu do faktu umierania, człowiek może poszukiwać sensu i związku ze śmiercią w swojej codzienności lub obserwując codzienność osób chorych. Tworząc tło do swojej interpretacji śmierci, korzysta z wielu płaszczyzn. Psychologia zakłada, że tłem dla ludzkich interpretacji faktu śmierci może być bardzo szerokie pole okoliczności. Doświadczenie śmierci może być oparte na różnych okolicznościach życiowych, na kontakcie z rzeczywistym umieraniem bądź ze śmiercią drugiej osoby. Ważnym elementem badającym doświadczanie śmierci w psychologii jest skupienie

37 A. Widera-Wysoczańska, op. cit., s. 62.

${ }^{38}$ M. Zimnoch, Śmierć przywrócona. Ludobójstwo w reportażach Wojciecha Tochmana, „Ruch Literacki" 2013, z. 6 (321), s. 675. 
się nie tylko na samej osobie badanej, ale na całym jej środowisku kulturowym wraz z rzeczywistością, w której funkcjonuje ${ }^{39}$. Zanurzenie się człowieka w świecie mediów on-line sprawia, że stają się one ważnym elementem służącym do poznania i interpretacji poszczególnych zjawisk, co tłumaczyłoby potrzebę komentowania postów zamieszczonych na koncie facebookowym zmarłej Anny Przybylskiej, a także śledzenia ich cykliczności. Ponadto, zdaniem Waltera, żałoba nie tyle dokonuje się podczas pracy z emocjami, co umożliwia uwolnienie się od przywiązania do zmarłego, ale żałoba dokonuje się $\mathrm{w}$ traktacie procesu społecznego: poprzez komunikację z innymi, umożliwiając uwolnienie się od przywiązania do zmarłego. Dawne rytuały stały się jałowe, pobawione treści, dlatego zostały zastąpione przez potrzebę dyskursu ${ }^{40}$. Diogenes Laertios, pisząc o doświadczaniu cudzej śmierci, zauważył, że śmierć drugiej osoby, śmierć kogoś bliskiego to „uprzywilejowane doświadczenie filozoficzne". Kiedy umiera inny człowiek, można zobaczyć jego śmierć (jego umieranie), można go ujrzeć martwym. Mimo że śmierć dotyczy kogoś innego, dotyka obserwatora bezpośrednio, ponieważ śmierć czyjaś przypomina naszą własną. Co więcej, kiedy umiera ktoś inny, oznacza to, że obserwator przeżyje ${ }^{41}$. Podobne stanowisko filozoficzne dotyczące przeżywania śmierci przyjął Louis-Vincent Thomas, który zauważa, że człowiek, opłakując kogoś drugiego, opłakuje także siebie - „moje umieranie”. „Umierając, druga osoba umiera moją śmiercią” - mówi filozof ${ }^{42}$. Facebook to zatem miejsce kontemplacji i zadumy. Ludzie biorący udział we wspólnym przeżywaniu i doświadczaniu cudzej śmierci w medium przypisują mu głębsze znaczenie; dla niektórych istnienie konta zmarłej aktorki jest związane $\mathrm{z}$ niesieniem misji, przekazywaniem głębszego, ukrytego przekazu, do którego prowadzi refleksja nad sobą i światem, możliwa dzięki wspólnej interpretacji zamieszczonych na stronie wpisów.

Internautka „Sandra Dobrzyńska” wierzy, że jej obecność, podobnie jak innych osób odwiedzających fanpage, pozwoli ulżyć bliskim zmarłej w przeżywaniu ich żałoby. Jest to dla niej również źródło pozytywnych emocji, których nośnikiem są zamieszczane tam fotografie i komentarze. Ponadto jej obecność na fanpage’u ma wymiar wspólnotowy:

Sandra Dobrzyńska: Jest tysiące osób, które zaglądają tu codziennie, aby powspominać, aby sobie przypomnieć, co jest w życiu ważne, aby podzielić się swoją tęsknotą za Anią, wierząc, że choć trochę to może ulżyć bliskim Ani, że nie są osamotnieni w tej tęsknocie za jej pięknem... Dziękuję osobie prowadzącej ten profil za to, że nadal ma siłę go prowadzić - dla nas, wszystkich fanów Ani... Pozdrawiam.

Źródło: https://www.facebook.com/aniablond/timeline, 4.12.2014.

39 Ibidem, s. 62.

40 A.E. Kubiak, op. cit., s. 46.

41 D. Laertios, Żywoty i poglądy słynnych filozofów, przeł. K. Leśniak, PWN, Warszawa 1968, X 125, s. 645.

42 A. Widera-Wysoczańska, Rozmowy o przemijaniu. Hermeneutyczna analiza psychologiczna człowieka, Wydawnictwo Uniwersytetu Wrocławskiego, Wrocław 2000, s. 33. 
„Monika Kropidłowska” wierzy, że istnienie fanpage’a ma ukryte przesłanie, a jego stała aktualizacja jest wolą zmarłej:

Monika Kropidłowska: Skoro ktoś ma hasło, to nie sądzicie, że taka była wola Ani? Doczytajcie teksty niektóre, może trzeba dwa razy, by zrozumieć przesłanie. Mnie np. bardzo ten wpis cieszy.

Źródło: https://www.facebook.com/aniablond/timeline, 4.12.2014.

Dla innych („Alina Chmielowiec”, „Izabela Grażyna Szczęsna”, „Aneta Sulikowska") zaglądanie na profil ma moc terapeutyczną, ponieważ jest źródłem pozytywnych wzmocnień wyzwalanych przez obrazy odwołujące się do wspomnień z życia aktorki.

Izabela Grażyna Szczęsna: dziękuję za te wspomnienia i za to, że cały czas się o niej pisze... Źródło: https://www.facebook.com/aniablond?fref=ts, 4.12.2014.

Alina Chmielowiec: Po to jest ten profil, żeby móc na niego zaglądać, wspominać, pisać i pamiętać o Ani. Wielu ludziom to pomaga. Jeżeli komuś się to nie podoba, to niech tu w ogóle nie zagląda.

Źródło: https://www.facebook.com/aniablond/timeline, 4.12.2014.

Dodatkowo, dla „Anety Sulikowskiej” istnienie fanpage’a jest przykładem świadectwa, które zostawiła po sobie „Piękna i obdarowana darem normalności Anna Przybylska”.

Aneta Sulikowska Kocerka: Pięknie dziękuję za te wspomnienia - bolesne, ale tak bardzo potrzebne... po cichutku liczę na książkę o Pięknej i obdarowanej darem normalności Annie Przybylskiej $<3<3<3$

Źródło: https://www.facebook.com/aniablond?fref=ts, 11.12.2014.

„Ag Ag” zagląda na profil, żeby poszukiwać odpowiedzi na pytania egzystencjalne, zrozumieć istotę przemijania i śmierci, podobnie jak „Gosia Sawicka”, która utożsamia Annę Przybylską z jej pozytywnym wizerunkiem medialnym i rolami, jakie grała, będąc aktorką. Serialowa bohaterka była jej bliska, dlatego też odwiedzając jej profil, może kontynuować przyjemność ze spotkania z nią po drugiej stronie ekranu.

Gosia Sawicka: Jest mi miło, że mogę oglądać zdjęcia Ani i czytać teksty o Niej. Anię znałam tylko z ekranu, a czułam się tak, jakbym straciła bliską mi osobę. Dlatego jestem wdzięczna rodzinie Ani, że mogę nadal o Niej czytać.

Źródło: https://www.facebook.com/aniablond/timeline, 4.12.2014.

Ag Ag: To strasznie smutne. Codziennie myślę o Ani. O tym, co musiała przeżyć, co czuć, wiedząc, że umiera. Jak żegnała się z rodziną, z dziećmi, aż serce boli. Dlaczego tak kochana, dobra osoba musiała aż tak cierpieć i odejść tak wcześnie... nigdy tego nie zrozumiem i nikt nie będzie w stanie mi tego wytłumaczyć.

Źródło: https://www.facebook.com/aniablond/timeline, 4.12.2014. 
„Małgorzata Beyer-Piątek”, odwiedzając fanpage Przybylskiej, nie czuje się odosobniona ze swoimi doświadczeniami związanymi ze stratą bliskiej osoby, utożsamia się z bohaterką fanpage’a i stawia ją za przykład „silnej kobiety - prawdziwej matki" walczącej z przeciwnościami losu. W jej przekonaniu prawdziwa matka to kobieta obdarowana cechami Anny Przybylskiej. Tym samym staje się ona wzorem do naśladowania dla współczesnych kobiet.

Małgorzata Beyer-Piątek: Gdy czytam tę historię, urywki z życia tej wspaniałej kobiety, łzy cisną się niesamowicie. Wiem, co to stracić kogoś, ale staram się być silna jak Ania, walczyć do końca. Prawdziwa, dzielna matka.

Źródło: https://www.facebook.com/aniablond/timeline, 4.12.2014.

Podobnie z Anną Przybylską utożsamia się „Asia Sz”, która posługuje się w swojej wypowiedzi jednym $\mathrm{z}$ cytatów stanowiących fragment jej wypowiedzi zamieszczonej na fanpage'u. „Asia Sz" boi się, że spotka ją ten sam los co Przybylską: „Jestem w tym samym wieku, mam małe dzieci i już jestem obciążona $\mathrm{z}$ obu stron" - zauważa. Zapowiada jednak, że (wzorując się na wizerunku aktorki przedstawionym na stronie) będzie walczyć, „przesterowując swoją głowę na pozytywne myślenie". Cytat ten ma dla niej kluczowe znaczenie, stanowi motywację do działania i staje się mottem przewodnim, który odtąd będzie wykorzystywała w swojej walce o siebie, rodzinę, wartości. „Asia Sz” wyobraża sobie siebie w podobnej sytuacji i pisze o emocjach, które w związku z tym odczuwa:

Asia Sz: Tak sobie myślę, dlaczego tak jest - Ania najbardziej bała się choroby i śmierci w młodym wieku, a zwłaszcza bała się o dzieci, które zostałyby bez mamy, i to od losu dostała, moja koleżanka najbardziej w życiu bała się tego, że jak będzie jeździła do pracy rowerem, to potrąci ją samochód, i jeździła wobec tego chodnikiem, któregoś razu, wymijając przechodniów, spadła $\mathrm{z}$ tego chodnika prosto pod auto, finał wiadomy, została 5-letnia córeczka - od życia dostajemy to, czego najbardziej nie chcemy, czego się obawiamy... Moja mama zmarła, jak byłam na ostatnim roku studiów - białaczka, teraz choruje tata, guz pęcherza - nienawidzę tej choroby, w każdej prawie rodzinie się pojawia, niszczy młodych, starszych, całe rodziny!!! Wiem, jak bardzo brakuje mamy przez całe późniejsze życie.... tak mi szkoda tych dzieci, one jeszcze takie małe. Dużo przemyśleń w mojej głowie się pojawiło, jak usłyszałam tę tragiczną wiadomość, i myślę sobie, że też będę musiała przesterować swoją głowę na pozytywne myślenie, bo straszna ze mnie pesymistka, a też jestem w podobnym wieku i mam małe dzieci, i już jestem obciążona z obydwu stron. Jeszcze nigdy nie dotknęła mnie tak bardzo śmierć obcej osoby jak ta, chociaż uważam też, że nie należy umniejszać niczyjej śmierci, codziennie umierają na tę straszną chorobę ludzie, tylko jest to tragedia o dużo mniejszym rozgłosie, ale nie mniej bolesna - przeżywana w gronie rodziny, bliższych i dalszych znajomych. Nie mogę tego przyjąć do wiadomości, ciągle o tym myślę i tak bardzo mi żal Ani i całej jej rodziny... dzieci i Jarka przede wszystkim. Taką ją zapamiętam - wspaniała mama, piękna, dowcipna dziewczyna z dystansem do siebie... Aniu, spoczywaj w pokoju i miej w opiece całą swoją rodzinę $\left[{ }^{\star}\right]\left[{ }^{\star}\right]$... dla Ani Przybylskiej ... $\left.{ }^{\star}{ }^{\star}\right]$

Źródło: https://www.facebook.com/aniablond/timeline, data: 4.12.2014. 
Rosnąca świadomość ludzi na temat śmierci i jej nieuchronności sprawia, że częste pokazywanie w mediach i prasie ludzi młodych, a także życie w poczuciu stałego zagrożenia choroby sprawia, iż „Sztuczne odseparowanie życia i śmierci nie daje szansy na ucieczkę od niej - świadomość jej istnienia towarzyszy tak naprawdę każdej istocie i nie sposób zaprzeczyć mało odkrywczemu stwierdzeniu, że żyjemy w cieniu śmierci. I właśnie ta świadomość (...) powoduje, że człowiek zanurzony w miejskiej dżungli i zdominowany przez krótkoterminowość i przyjemność ma potrzebę "oswajania śmierci «" ". W 2000 roku w książce Hospicjum w stużbie umierającym Mirosław Górecki pisał, że śmierci nie można poznać poprzez wgląd w śmierć drugiego człowieka. Można jedynie stwierdzić, że ktoś umarł, natomiast samej istoty przeżywania i doświadczania nie jesteśmy w stanie posiąśćc ${ }^{44}$. Wydaje się, że w ciągu ostatnich piętnastu lat w wyniku wzrostu technologii informacyjnych i wykształceniu się social mediów żyjemy coraz bliżej śmierci. Właściwie oglądamy ją codziennie, w telewizji i Internecie, przybiera ona tylko mniej lub bardziej szokujące formy. Obcowanie ze śmiercią i czucie jej oddechu na plecach sprawia, że chce się ją poznać poprzez wyobrażenie sobie siebie w sytuacji zagrożenia śmiertelną chorobą. Współczesny człowiek, poznając istotę śmierci, pyta, jak to jest wiedzieć, że się umrze, a odpowiedzi na to pytanie, tak jak w przypadku innych problemów, dostarczają mu media, w tym przypadku Facebook. „Anna Machoń” zauważa, że „rozum ludzki nie ogarnia” walki z emocjami, które towarzyszą tragizmowi śmierci; podobnie „Magda Białkowska” pisze, że ludzki umysł nie pojmuje sytuacji, w której ktoś odchodzi.

Anna Machoń: Rozum ludzki nie ogarnia, co musi czuć matka żegnająca się ze swoimi nastoletnimi dziećmi i malusieńkim 3-latkiem, oczkiem w głowie, wiedząc, czując, że to jest ostatnie spojrzenie tych pięknych, ogromniastych oczu, widok dzieci, którego nigdy nie ma się dość i nigdy się nie nudzi. 8 października o 09:56.

Źródło: https://www.facebook.com/aniablond?fref=ts, 12.12.2014.

Magda Białkowska: Taka szczęśliwa i kochająca się Rodzina. Żal niewyobrażalny. Od poniedziałku, gdy się dowiedziałam o Twej śmierci, Aniu, nie mogę się normalnie pozbierać, mimo że jestem dla Ciebie obcą osobą. Tak bardzo żal mi Twych dzieci i Ciebie, bo tak je kochałaś. Jarek i Twoja mama... Dlaczego Bóg tak boleśnie doświadcza? Tego nasz ludzki umysł nie pojmuje. 10 października o 21:00.

Źródło: https://www.facebook.com/aniablond?fref=ts, 12.12.2014.

Zamieszczone na koncie facebookowym nieżyjącej już aktorki wpisy stanowią pewnego rodzaju opis przeżyć, których doświadcza człowiek, kiedy oddaje się rozważaniom nad własną egzystencją w sytuacji, gdy przychodzi mierzyć mu się z chorobą. Wśród nich znajduje się lęk przed chorobą, starością, osamotnieniem,

${ }_{33}$ M. Tomiczek, Tragizm, rozrywka, edukacja - różne obrazy śmierci w mediach jako próba przekroczenia tabu śmierci i umierania, w: A. Gralczyk, M. Laskowska, P. Dziewiecki (red.), Media wobec śmierci, t. 2, op. cit., s. 22.

${ }^{44}$ M. Górecki, Hospicjum w stużbie umierajacych, Wydawnictwo Akademickie Żak, Warszawa 2000 , s. 16. 
przemijaniem. Czytelnik konfrontujący się z podobnymi dylematami, poznając oblicza cudzej śmierci, analizując przeżycia innych (w tym przypadku zmarłej Anny Przybylskiej), interpretuje własne obawy i szuka spokoju, oswaja się ze swoimi słabościami i lękiem. Co więcej, doświadczenia odbiorcy występują tu jako rezultat działań administratora strony i są wynikiem analizy kognitywnej (poznawczej) oraz afektywnej (emocjonalnej) w umyśle odbiorcy. Na skutek powiązania czynników motywacyjnych, osobistych wartości odbiorcy oraz jego doświadczeń stają się one podstawą dalszego kształtowania własnych wrażeń, poglądów, odczuć czy też nadawania pewnym zdarzeniom określonej symboliki ${ }^{45}$ („Asia Sz”).

Chęć poznania oblicza śmierci jest podyktowana lękiem przed nią, który nabiera szczególnego wyrazu w momencie uruchomienia przez człowieka wyobraźni i próby zamknięcia go w ramy rozumowania. Józef Makselon podaje, że lęk przed śmiercią jest zjawiskiem wieloaspektowym i zamyka się w ośmiu rodzajach: lęku przed umieraniem, lęku przed zmarłym, lęku przed zniszczeniem ciała, lęku o żyjących, lęku przed nieznanym, lęku przed pozornym zgonem, lęku o wygląd ciała, lęku przed przedwczesną śmiercią. O ile lęk przed zniszczeniem ciała oraz lęk o wygląd mają charakter czysto fizyczny, o tyle pozostałe elementy przybierają wymiar duchowy i egzystencjalny. Cielesność można dziś stale poprawiać, udoskonalać i odnawiać, by oszukać czas ${ }^{46}$. Lęk przed śmiercią jest związany z jej nieodwracalnością ${ }^{47}$. Zdaniem Adama Szostkiewicza „Śmierć dla współczesnego człowieka jest skandalem. Człowiek zawsze był bezradny wobec śmierci, ale dopiero w naszych czasach przestaje wiedzieć, jak z nią w ogóle zmierzyć się myślowo, duchowo oraz moralnie"48. Istnieje zatem potrzeba poznania istoty doświadczania śmierci: od osób śmiertelnie chorych oczekuje się przesłanek i wskazówek jak żyć ze świadomością jej nieuchronności. Media to ułatwiają. W Internecie można kilka razy wejść na profil osoby chorej, przeczytać jej zapiski i powracać do nich kilka razy dziennie, wczytując się od nowa w ich treść, by poszukać głębszego sensu życia i śmierci. Ludzie oczekują haseł i prawd życiowych od osób nieuleczalnie chorych, ponieważ choroba skłania do refleksji i często jest zwrotem ku wartościom, za którymi się tęskni i które się porzuca na rzecz wygody i uznania.

Agnieszka Widera-Wysoczańska przekonuje, że przeżywanie śmierci i ustosunkowywanie się do niej jest zjawiskiem przeżyciowym, o charakterze interpretacyjnym i zmiennym, który spełnia się w poszczególnych doświadczeniach człowieka. Śmierć może mieć wymiar rzeczywisty, wyobrażeniowy oraz oparty na refleksji.

${ }^{45}$ I. Skowronek, Marketing doświadczeń jako wyznacznik wizerunku i wartości przedsiębiorstwa, „Zeszyty Naukowe Uniwersytetu Szczecińskiego” 2013, nr 658, s. 211.

${ }^{46}$ Większe piersi na imprezę? 20 minut i gotowe, http://www.tvn24.pl/ciekawostki-michalki,5/ wieksze-piersi-na-impreze-dwadziescia-minut-i-gotowe,490023.html [dostęp: 3.02.2014].

47 A. Widera-Wysoczańska, Problemy śmierci w poglądach młodych ludzi, „Zdrowie Psychiczne” 1988, nr 3-4, s. 157-169.

${ }^{48}$ Za: A.M. Pycka, Ars moriendi w wydaniu ponowoczesnym, w: A. Gralczyk, M. Laskowska, P. Dziewiecki (red.), Media wobec śmierci, t. 2, op. cit., s. 29. 
Sposób mówienia o niej prezentuje jej sposób przeżywania, nadawania jej określonego znaczenia, który często zamknięty jest w metaforach językowych. Przykładem użycia metafory językowej jest poniższy wpis:

Wyspowiadałam się pierwszy raz od 13 lat. Teraz znowu kumpluję się z Panem Bogiem, chodzimy co niedziela na kawę. Bardzo dobrze mi z tą przyjaźnią, lecz nie narzucam nikomu mojej wiary, nie manifestuję jej i nie zmuszam innych, aby razem ze mną na tę niedzielną kawę chodzili. Ale uwierz mi, że po tych spotkaniach jest mi naprawdę o wiele lżej. I myślę, że dostałam swoją lekcję od Niego w jakimś celu. Po coś...

Anna Przybylska, https://www.facebook.com/aniablond, „Viva!”, luty 2014.

Powyższy wpis wyraźnie wskazuje na nadawanie znaczenia śmierci i swoisty sposób jej przeżywania (oswajania). Można w nim również odnaleźć przeżywaną przez aktorkę fazę lęku związaną ze śmiercią. Jerzy Stochmiałek podaje, że „Ten, kto otrzymał już informację o własnej śmierci i przeżył już gniew na tych, którzy mu tę informację przekazali, w etapie targowania się próbuje oddalić moment wykonania tego, co i tak ma przyjść, czyli chce jakby rozcieńczyć czas, rozciągnąć go, obiecując w zamian dostosowanie się do poleceń lekarzy, rodziny oraz często poprawę etyczno-religijną. Byleby tylko mieć jeszcze trochę czasu. (...) Lęk maleje u osób prezentujących religijność" ${ }^{49}$.

Znaczenie, które aktorka nadała sobie i otaczającej jej rzeczywistości, wyraża się też w przesłaniu:

Czynienie dobra powinno przede wszystkim dotyczyć nas samych. Wyzbywam się więc złych emocji, które nagromadzone we mnie sprawiają, że cierpią na tym najbliższe mi osoby. Staram się więc nie ulegać impulsom, nie złościć, być po prostu na co dzień życzliwą. To działa w obie strony, bo im ja jestem lepsza dla siebie, tym jestem lepsza dla innych.

Anna Przybylska, https://www.facebook.com/aniablond.

Lęk przed chorobą i zmianą, a także przemijaniem wyrażony został w poniższych cytatach:

Boję się czasu. I to nie zmarszczek czy cellulitu. Z tym sobie można poradzić. Chociaż jestem młoda i energiczna, często martwię się na zapas, bo boję się cierpienia, odchodzenia i przemijania. Nie własnego, tylko bliskich.

Anna Przybylska, „Viva!”, 2011, https://www.facebook.com/aniablond.

Boję się tylko choroby. Takiej, która wywraca twój świat do góry nogami. A czas? Powiem nieskromnie, że czas mnie nie dotyka. Trochę co prawda wkurza mnie technologia HD, dzięki której na ekranie widać każdą zmarszczkę i starą raszplę zamiast ponętnej kobiety, ale na razie się trzymam. Nie farbuję włosów, bo nie znalazłam jeszcze na głowie ani jednego siwego, do twarzy używam tylko kremu dla dzieci, a nie tych drogich wynalazków, dbam o ciało, dużo ćwiczę - jestem przecież aktorką, a to mój warsztat pracy.

Anna Przybylska, https://www.facebook.com/aniablond, „Cosmopolitan”, maj 2013.

${ }^{49}$ J. Stochmiałek, Przemijanie i śmierć w refleksji andragogicznej, „Edukacja Ustawiczna Dorosłych" 2001, nr 1 (32), s. 27. 
Swoisty sposób radzenia sobie w traumatycznej sytuacji życia w cieniu śmierci prezentuje poniższy wpis:

Ja myślę teraz krótkoterminowo, nie ma co wybiegać za bardzo w przyszłość. Nie mogę się doczekać wiosny (...). Przesterowałam moją głowę na pozytywne myślenie, żeby cieszyć się życiem. I walczyć, bo mam o co. Ja teraz rozumiem, co to znaczy naprawdę cieszyć się każdą chwilą. Doceniam każdą minutę.

Anna Przybylska, https://www.facebook.com/aniablond, „Viva!”, luty 2014.

\section{Po co nam doświadczać cudzej śmierci na Facebooku?}

Żyjemy w czasach, w których śmierć zyskała miano „ponowoczesnej”. Walter w zaproponowanej przez siebie typologii śmierci wyróżnił ponowoczesną śmierć jako taką, która stoi w opozycji do śmierci tradycyjnej i nowoczesnej. „Do tradycyjnej kondycji należy życie ze śmiercią, do nowoczesnej - śmierć zaprzeczona, do ponowoczesnej - życie z umierającymi uosobione w mottach: »życie z rakiem « czy »życie z HIV «"50. Ponowoczesna śmierć uwzględnia niepewność i ryzyko współczesnej kultury, co ma odzwierciedlenie w mediach. Zygmunt Bauman trafnie zauważa, że współczesna śmierć jest związana $\mathrm{z}$ chorobą i przedstawiana jako jej wynik. Ponadto „umieranie jest jednym $z$ licznych widowisk, które składają się na Lebenswelt współczesnego kino- czy wideomana. Jak wszystkie widowiska, umieranie [jest] dramatem rozgrywanym w rzeczywistości wirtualnej - realnej, namacalnej - nie dotyczy już bohaterów Star Treka, czterech czołgistów tudzież psa, żonglujących pistoletami kowbojów czy uzbrojonego po zęby Rambo" ${ }^{51}$. Analizowany przypadek Facebooka stanowi opis przygotowywania się do śmierci, przedstawia refleksję o niej z punktu widzenia żywej, ale już zmarłej osoby. Rzeczywistość wirtualna, będąca tu sceną, na której rozgrywał się dramat choroby - „życia z rakiem”, opowiedziała jednostkową historię osoby, którą można $z$ łatwością porównać i utożsamić z własnymi obawami o siebie i bliskich, ponieważ śmierć jest dziś zagrożeniem dla życia. Odczuwanie grozy śmierci jest dzisiaj powszechne: „Śmierć puka do drzwi dzień po dniu i przez dwadzieścia cztery godziny na dobę, za każdym razem jednak w innym przebraniu: raz w stroju zwierzęcego tłuszczu, innym razem pod postacią zakażonych listerią jaj, bogatych w cholesterol ciastek, seksu bez prezerwatywy, dymu papierosowego, astmogennych żuczków dywanowych, bakterii i wirusów zaczajonych w zlewie, wyziewów zaprawionej ołowiem benzyny i wody pitnej fluoryzowanej, niedostatecznego wysilania ciała i nadmiernego wysiłku, objadania się i przesadnego odchudzania, nadmiernego stężenia ozonu w powietrzu i dziury ozonowej w powłoce" 52 .

${ }^{50}$ A.E. Kubiak, Inne śmierci. Antropologia umierania i żałoby w ponowoczesności, Universitas, Kraków 2014, s. 43.

${ }^{51}$ Z. Bauman, Ponowoczesność jako źródło cierpień, Sic!, Warszawa 2000, s. 301.

52 Ibidem, s. 300. 
W XXI wieku śmierć nie jest już tematem tabu, a świadectwa osób umierających wymuszają dyskusje i chwilowe zastanowienie się nad tym tematem. Dzieje się tak, ponieważ „zagrożenia cywilizacji prowadzą nas do powstania pewnego rodzaju »królestwa cieni«, porównywanych z bóstwami i demonami wczesnych wieków, które ukryte przed widzialnym światem zagrażały życiu ludzkiemu. Nie komunikujemy się już dzisiaj z duchami, które tkwią w rzeczach, ale czujemy się wydani na promieniowanie. Łykamy toksyczne substancje i nawet w snach prześladuje nas lęk przed atomowym holocaustem. Miejsce antropomorficznej interpretacji natury świata zajęła nowoczesna, cywilizacyjna świadomość ryzyka ze swoją niepoznawalną, ale jakże wszechobecną ukrytą przyczynowością (...). Zewsząd chichoczą i grasują jak średniowieczny diabeł szkodliwe i trujące substancje. Ludzie wydani są bez reszty na ich pastwę. Wszystko jest nimi przesiąknięte - oddech, jedzenie, mieszkanie, odzież. Są one [toksyny] - podobnie jak ścigający się z zającem jeż - zawsze pierwsze na mecie" 53 .

Wydaje się, że owym demonem Becka jest choroba nowotworowa, od której nie ma ucieczki, jeśli „zostaniesz nominowany”. Człowiek co dzień skazany jest na nieświadome zażywanie toksycznych substancji, ponieważ kryją się one nawet w „ziarnach naszej ucieczki” ${ }^{44}$ (odwołanie do zdrowej żywności, produktów wielozbożowych mających stanowić antidotum na choroby cywilizacyjne), sprawiając, że człowiek współczesny żyje w nieustannym lęku cierpienia i choroby, która zawładnęła królestwem cieni, pozwalając nielicznym wyrwać się z jej sideł.

Sartre trafnie zauważa, że jeden $z$ fenomenów i jednocześnie absurdów śmierci wyraża się w tym, że przychodzi w czasie i w sposób, w jaki ona chce, a nie wtedy, kiedy my sobie tego życzymy. Śmierć jest poza kontrolą, napawa lękiem, bo nie można wpisać jej w ramy audytu idei nowoczesności: kontroli, planowania, panowania nad naturą, kreowania siebie, przeświadczenia o swojej władzy absolutnej ${ }^{55}$. Wpisy na facebookowym koncie Anny Przybylskiej dotyczące doświadczania śmierci wyraźnie uświadamiają współczesnemu człowiekowi, że w świecie, w którym można być, kim się chce, kreować na wiele sposobów własną tożsamość, stając się człowiekiem sukcesu, śmierć zawsze może pojawić się niepostrzeżenie, niwecząc plany i marzenia. Człowiek nagle zdaje sobie sprawę, że nie jest „Panem życia”, ponieważ w jego egzystencji ważną rolę odgrywa kostucha. „Śmierć kieruje się własnymi racjami, eliminując wszystkie możliwości osoby i usuwając wszelki sens życia" 56 .

Nowotwory trzustki są nowotworami ludzi starych, a nie takich jak Ania. Kiedy ją poznałem, była osobą pełną życia. Zresztą do końca była taka, mimo tego, że widziałem ją

${ }^{53}$ U. Beck, Społeczeństwo ryzyka. W drodze do innej nowoczesności, Wydawnictwo Naukowe Scholar, Warszawa 2002, s. 94-95.

${ }^{54}$ Ibidem, s. 95.

${ }_{55}$ Z. Bauman, Śmierć i nieśmiertelność. O wielości strategii życia, Wydawnictwo Naukowe PWN, Warszawa 1998, s. 160.

${ }^{56} \mathrm{Za}$ : A. Widera-Wysoczańska, op. cit., s. 30. 
w stadium, w którym niewielu z Państwa chciałaby ją widzieć, kiedy dopadał ją ból, że niemal wyła. Nie było w niej nic z gwiazdy. Była skromną dziewczyną proszącą, byśmy w miarę możliwości zachowali dyskrecję. Ania walczyła o każdy dzień. Nie jakoś natarczywie, nienachalnie, nie mówiąc „należy mi się". Walczyła tak jak każdy inny chory i to jest coś, co w niej ceniłem. Miałaby możliwości, jak Steve Jobs, by poruszyć niebo i ziemię, by jej można było pomóc. Wykorzystała to, co mogła. Niestety choroba była zbyt poważna. 6 październik 2014.

dr hab. n. med. Dariusz Zadrożny dla TVP Info Źródło: https://www.facebook.com/aniablond?fref=ts, 12.12.2014.

Facebook, podobnie jak cały Internet, upublicznia śmierć. Śmierć ta odbywa się w przestrzeni otwartej dla każdego, w każdym czasie. Konta-wspomnienia osób zmarłych prowadzone na Facebooku mają charakter performatywny - zachęcają, aby każdy dodał coś od siebie, skomentował wpis, opowiedział własną historię, wyraził swój żal, złożył kondolencje, zapalił wirtualny znicz za pomocą emotikonu, wstawił obrazek żałobny. Przestrzeń ta ma również charakter addytywny - na co wskakuje stała liczba dodawanych nowych postów.

Przeżywanie żałoby na Facebooku ma charakter niekończącego się przeżycia, ponieważ stale dodawane są nowe zdjęcia, nowe przemyślenia, cytaty. Jest to szczególne miejsce, które umożliwia autobiograficzny imperatyw: prowadzenie ciągłej refleksji między sobą i innymi poprzez stałe rekonstruowanie minionych wydarzeń i ich interpretację.

Zdaniem Joanny Tokarskiej-Bakir przeżywanie żałoby i swoiste oswajanie śmierci za pomocą dialogu jest w dzisiejszym świecie utrudnione ze względu na zanik więzi międzypokoleniowych, separację rodzinnych sfer życia, mobilność społeczną. Ponadto tabuizacja żałoby pogłębia osierocenie osoby osamotnionej. Współczesny człowiek, wysiedlony z tradycji, miejsca i więzi ze „znaczącymi innymi", szuka przestrzeni do tworzenia nowych, zażyłych kontaktów z innymi osobami, poszukując niejako nowych sposobów żałobnej konwersacji. Internet jako medium komunikacyjne stał się niezwykle poręcznym narzędziem kommemoratywnej narracji. Szczegółowa narracja o tym, kim był zmarły, jakie relacje łączyły go z osobą piszącą, opis traumatycznej walki z chorobą i umieraniem osoba pisząca poddaje obiektywizacji i urefelksyjnieniu. Zamieszczone przez siebie wpisy, będące nierzadko relacją o minionych wydarzeniach, często czyta kilkakrotnie - dzięki temu spogląda na dokonany przez siebie zapis nie tylko jako twórca, ale także jako czytelnik. Warto dodać, że w sytuacji tej spełniony zostaje również warunek komunikacji z innymi. Człowiek ma poczucie podzielenia się własnymi przemyśleniami, często dostaje też potwierdzenie tego $\mathrm{w}$ formie kondolencyjnych komentarzy oraz w postaci symbolicznej ${ }^{57}$.

${ }^{57}$ J. Tokarska-Bakir, Obraz osobliwy. Hermeneutyczna lektura źródeł etnograficznych, Universitas, Kraków 2000, s. 134. 


\section{Zakończenie}

Omawiając zjawisko istnienia problematyki śmierci w Internecie, posłużyłam się analizą konta prowadzonego na Facebooku Anny Przybylskiej. Jak zaznaczyłam na początku, wybór nie był przypadkowy ze względu na popularność aktorki, jej wizerunek idola-ikony, specyficzną budowę jej fanpage’a, prezentowane na nim wzory tożsamości, a także konstrukcję postów, które wyraźnie wskazywały na sposób trwania aktorki w sytuacji trajektorii cierpienia opisywanej szerzej przez Fritza Schützego w jednej z zacytowanych prac. Przeanalizowany przeze mnie przypadek trwania na Facebooku mimo śmierci i przekształcenia konta lub celowego jego założenia w postaci wirtualnego pamiętnika nie jest odosobnionym przypadkiem. Ze względu na popularność i szczególne miejsce Anny Przybylskiej w społeczeństwie możliwe stało się opisanie sposobu doświadczania cudzej śmierci i cudzego umierania w kontekście całożyciowej egzystencji ludzkiej. Możliwe stało się również pokazanie, jak przekazy medialne wpływają na doświadczanie i dzielenie się tym, co łączy się z przemijaniem, tragizmem, cierpieniem, niesprawiedliwym losem. Konta-wspomnienia osób zmarłych prowadzone na Facebooku spełniają potrzebę łączenia się ludzi w bólu, żałobie, tęsknocie i osamotnieniu. Korzystanie z Facebooka wpisało się na dobre w codzienność wielu ludzi, o czym świadczy jego popularność i liczba użytkowników. Codzienność ta znajduje swój wyraz w doświadczaniu, interpretowaniu i negocjowaniu znaczeń, a dzięki szeroko rozwiniętej komunikacji internetowej staje się nieformalną grupą wsparcia dla tych, którzy kogoś stracili. Dalsze administrowanie kontem zmarłej osoby jest jedną ze współczesnych strategii radzenia sobie z traumą i jednym ze sposobów na oswajanie śmierci. Konta-wspomnienia czy wirtualne pamiętniki osób zmarłych pozwalają na autorefleksję i są miejscem zadumy. Facebook to ważne miejsce przeżywania żałoby, dzielenia się refleksją nad przemijaniem, a także poszukiwania i wspólnotowego doświadczania tragedii. Pozwala na tworzenie się nieformalnych grup wsparcia dla osób mających podobne doświadczenia i przeżywających lęki związane ze stratą i cierpieniem. Jest również miejscem czerpania wzorów osobowych. Uczenie się siebie i oswajanie swoich emocji to proces, który jest możliwy poprzez konfrontowanie doświadczeń z przeżyciami innych i wchodzeniem z nimi w dialog. Posługiwanie się tym samym kodem znaków wyrażonym w emotikonach i obrazach daje głębokie poczucie wspólnoty wśród użytkowników tego portalu. „Odwieczna potrzeba złagodzenia bólu po śmierci bliskich jest zawsze taka sama. Internet daje tylko inną możliwość zaspokojenia tej potrzeby" ${ }^{38}$. Zawsze jednak podstawą łagodzenia bólu są ludzkie więzi. Facebook odgrywa tym samym ważne miejsce doświadczania i interpretowania śmierci.

${ }^{58}$ Za: A.E. Kubiak, op. cit., s. 183; Ł. Kapralska, A. Maksymowicz, op. cit., s. 207. 


\section{Bibliografia}

Anna Lewandowska pożegnała zmarła przyjaciółkę. Beata Maciejewska-Welfle nie żyje, 2.12.2016, http://www.pomponik.pl/plotki/news-anna-lewandowska-pozegnala-zmarla-przyjaciolke-beata-macieje,nId,2316389 [dostęp:13.02.2017].

Baran G., Marketing współtworzenia wartości z klientem, Instytut Spraw Publicznych Uniwersytetu Jagiellońskiego, Kraków 2013.

Bauman Z., Śmierć i nieśmiertelność. O wielości strategii życia, Wydawnictwo Naukowe PWN, Warszawa 1998.

Bauman Z., Ponowoczesność jako źródło cierpień, Sic!, Warszawa 2000.

Beck U., Społeczeństwo ryzyka. W drodze do innej nowoczesności, Wydawnictwo Naukowe Scholar, Warszawa 2002.

Co dzieje się z kontem na Facebooku po śmierci? Teraz można o tym zdecydować, http://www. tvp.info/18835527/co-dzieje-sie-z-kontem-na-facebooku-po-smierci-teraz-mozna-o-tym-zdecydowac [dostęp: 6.03.2017].

Daszczyński R., Najdroższa twarz Pomorza. Role w filmach, promocja kosmetyków, sesje w Playboyu, a do tego wizerunek dobrej matki i żony. Jakim cudem Anna Przybylska to wszystko łączy?, 29.06.2017, http://trojmiasto.wyborcza.pl/trojmiasto/1,35636,14192156,Anna_ Przybylska_na_zakrecie_Portret_znanej_aktorki.html [dostęp: 1.03.2017].

Dziewanowska K., Nowe oblicze marketingu - koncepcja marketingu doświadczeń, „Marketing i Rynek" 2013, nr 1/20.

Gietka E., Wirtualne życie umarlych. E-umarli, http://www.polityka.pl/tygodnikpolityka/ ludzieistyle/1559775,1,wirtualne-zycie-umarlych.read [dostęp:10.04.2015].

Górecki M., Hospicjum w stużbie umierających, Wydawnictwo Akademickie Żak, Warszawa 2000.

Gromkowska-Melosik A., Ikony i idole popkultury. Taylor Swift i Barbie jako wzory ciała $i$ tożsamości młodzieży, w: J. Pyżalski (red.), Wychowawcze i społeczno-kulturowe kompetencje współczesnych nauczycieli, theQ studio, Łódź 2015.

Gromkowska-Melosik A., Od skromnej dziewczyny z sasiedztwa do bohaterki postfeministycznego świata, „Studia Edukacyjne” 2015, nr 36.

Jarkiewicz K., Wirtualna religijność w polskim Internecie, „Perspektywy Kultury” 2012, nr 72.

Jeleń-Kubalewska J., Cierpienie i śmierć jako współczesny performans medialny. Perspektywa performatywna, Praca doktorska sfinansowana przez Narodowe Centrum Nauki jako projekt badawczy w ramach konkursu „Preludium”, Poznań 2011.

Juszczyk S., Badania jakościowe w naukach społecznych. Szkice metodologiczne, Wydawnictwo Uniwersytetu Śląskiego, Katowice 2013.

Kapralska Ł., Maksymowicz A., Internet jako Theatrum śmierci. O przeżywaniu umierania, cmentarzu i żałobie w wirtualnym świecie, „Kultura i Społeczeństwo” 2009, nr 3.

Kapuściński R., Lapidaria, Agora, Warszawa 2008.

Kobieta relacjonowała na Facebooku... zastrzelenie swojego chłopaka! „Boże, nie pozwól mu umrzeć, on jest niewinny!", http://www.pudelek.pl/artykul/94931/kobieta_relacjonowala_ na_facebooku_zastrzelenie_swojego_chlopaka_boze_nie_pozwol_mu_umrzec_on_jest_ niewinny/\# [dostęp: 13.02.2017].

Kobieta umierała podczas transmisji live na Facebooku. Nikt z ogladających jej nie pomógł, 3.01.2017, http://noizz.pl/spoleczenstwo/facebook-keiana-herndon-zmarla-podczas-transmisji-live/ny9nqfq [dostęp: 13.02.2017].

Kubiak A.E., Inne śmierci. Antropologia umierania i żałoby $w$ ponowoczesności, Universitas, Kraków 2014. 
Laertios D., Żywoty i poglądy stynnych filozofów, przeł. K. Leśniak, PWN, Warszawa 1968.

Nastolatka popelniła samobójstwo, transmitując je na żywo na Facebooku, 13.01.2017, http:// www.newsweek.pl/swiat/spoleczenstwo/nastolatka-popelnila-samobojstwo-transmitujac-je-na-zywo-na-facebooku,artykuly,403438,1.html [dostęp: 12.02.2017].

Nowak-Dziemianowicz M., Czy świat człowieka ma postać narracji? O możliwościach badania, rozumienia, zmiany, w: E. Kurantowicz, M. Nowak-Dziemianowicz (red.), Narracja - krytyka - zmiana - praktyki badawcze, DSWE TWP we Wrocławiu, Wrocław 2007.

Pietrzak A., Śmierć $w$ Internecie. Internet jako teren badań i źródło wiedzy etnograficznej, w: E.A. Jagiełło, P. Schmidt (red.), Homo Interneticus? Etnograficzne wędrówki w głąb sieci, Wiedza i Edukacja, Lublin 2010.

Pożegnat się ze znajomymi na Facebooku i zaraz potem został zastrzelony, 21.01.2017, http:// tech.wp.pl/pozegnal-sie-ze-znajomymi-na-facebooku-i-zaraz-potem-zostal-zastrzelony-6034886643451009a [dostęp: 13.02.2017].

Pycka A.M., Ars moriendi w wydaniu ponowoczesnym, w: A. Gralczyk, M. Laskowska, P. Dziewiecki (red.), Media wobec śmierci, t. 2: Tragizm, rozrywka, edukacja - różne obrazy śmierci w mediach jako przekroczenia tabu i śmierci, Dom Wydawniczy Elipsa, Warszawa 2012.

Schütze F., Trajektorie cierpienia jako przedmiot badań socjologii interpretatywnej, „Studia Socjologiczne" 1997, nr 1 (144).

Siuda P., Religia a Internet. O przenoszeniu religijnych granic do cyberprzestrzeni, Wydawnictwa Akademickie i Profesjonalne, Warszawa 2010.

Skoczek transmitował swoja śmierć na żywo na Facebooku, 21.08.2016, http://pikio.pl/skoczek-transmitowal-swoja-smierc-na-zywo-na-facebooku-video/\# [dostęp: 13.02.2017].

Skowronek I., Marketing doświadczeń jako wyznacznik wizerunku i wartości przedsiębiorstwa, „Zeszyty Naukowe Uniwersytetu Szczecińskiego” 2013, nr 658.

Stochmiałek J., Przemijanie i śmierć w refleksji andragogicznej, „Edukacja Ustawiczna Dorosłych" 2001, nr 1 (32).

Sudak I., Na wieki wieków Facebook, czyli co zrobić z profilem umarłego, http://wyborcza.biz/ pieniadzeekstra/1,134699,14873337,Na_wieki_wiekow_Facebook_czyli_co_zrobic_z_ profilem.html.

Szatur-Jaworska B., Analiza pamiętników jako metoda badawcza w nauce o polityce społecznej, „Problemy Polityki Społecznej. Studia i dyskusje” 2001, nr 3.

Szczepański J., Metoda biograficzna, w: idem, Odmiany czasu biograficznego, PWN, Warszawa 1973.

Tokarska-Bakir J., Obraz osobliwy. Hermeneutyczna lektura źródeł etnograficznych, Universitas, Kraków 2000.

Tomiczek M., Tragizm, rozrywka, edukacja - różne obrazy śmierci w mediach jako próba przekroczenia tabu śmierci i umierania, w: A. Gralczyk, M. Laskowska, P. Dziewiecki (red.), Media wobec śmierci, t. 2: Tragizm, rozrywka, edukacja - różne obrazy śmierci $w$ mediach jako przekroczenia tabu i śmierci, Dom Wydawniczy Elipsa, Warszawa 2012.

Widera-Wysoczańska A., Problemy śmierci w pogladach młodych ludzi, „Zdrowie Psychiczne” 1988, nr 3-4.

Widera-Wysoczańska A., Rozmowy o przemijaniu. Hermeneutyczna analiza psychologiczna człowieka, Wydawnictwo Uniwersytetu Wrocławskiego, Wrocław 2000.

Większe piersi na imprezę? 20 minut i gotowe, http://www.tvn24.pl/ciekawostki.

Wirtualne życie po życiu - posty na Facebooku i Twitterze po śmierci, 29.20.2013, http://tech.wp.pl/ wirtualne-zycie-po-zyciu-posty-na-facebooku-i-twitterze-po-smierci-6034800493142657a [dostęp: 17.02.2017].

Witek H., Śmiertelność - nieśmiertelność. Medialne konstrukcje i dekonstrukcje, w: A. Gralczyk, M. Laskowska, P. Dziewiecki (red.), Media wobec śmierci, t. 2: Tragizm, rozrywka, edukacja 
- różne obrazy śmierci w mediach jako przekroczenia tabu i śmierci, Dom Wydawniczy Elipsa, Warszawa 2012.

Zimnoch M., Śmierć przywrócona. Ludobójstwo w reportażach Wojciecha Tochmana, „Ruch Literacki” 2013, z. 6 (321).

Żona Tomasza Kality pożegnała go na Facebooku. „Będę zawsze tęsknič, 17.01.2017, http:// noizz.pl/spoleczenstwo/zona-tomasza-kality-pozegnala-go-na-facebooku-bede-zawsze-tesknic/pkjc84n [dostęp: 13.02.2017].

Życie po śmierci na Facebooku, 26.09.2017, http://kobieta.onet.pl/zdrowie/psychologia/zycie-po-smierci-na-facebooku/ty7ck [dostęp: 17.02.2017]. 